\title{
GAME THEORY APPLICATION IN DECISION MAKING OF HORTICULTURE FARMING
}

\author{
Putri Budi Setyowati ${ }^{*}$, Hery Toiba, Sujarwo, Syafrial, \\ Condro Puspo Nugroho \\ Department of Agricultural Economics, University of Brawijaya \\ *corresponding author: putri_budi@ub.ac.id
}

\begin{abstract}
In running farming system, farmers not only have a role important as owners who land they farm. But also they are as farm managers to make any decisions to face their farming problems under risk and uncertainty. These problems are categorized as internal and external factors related to price fluctuations of agricultural commodities. For that reason, farmers need to consider some strategies to overcome their farming problem for instance by choosing the best commodities that would give them an optimal profit. The maximax, maximin, savage, and laplace criterions were used to analyze decision making of horticulture farmer in determining which best horticultural commodities to plant according to their behaviour and attitude toward farming risk. Thus, horticulture farmer will be able to make a choice whether or not it is potato, cabbage, or, scallion that will be cultivated in the next planting period. Potato farmers are categorized as the optimistic farmer who loves farming risks and they are cautious. While scallion farmers are pessimistic farmers and they are risk averse. In addition, cabbage farmers are the ones who have the least regret.
\end{abstract}

Keywords: Decision Making, Game Theory, Uncertainty

http://dx.doi.org/10.21776/ub.agrise.2021.021.1.8

Received 25 January 2020

Accepted 28 January 2021

Available online 31 January 2021

\section{INTRODUCTION}

Horticulture farmers tend to have particular skill to support their role as farming owners and managers. That is why, they have to master any cultivation techniques and decision making skill for example in selecting plant varieties, fertilizer application, labour distribution, and marketing of agriculture production. Market describes an equal quantity of supply and demand (Hirshleifer, 1984).

The success of farming activities are affected by internal and external factors. Limited capital can be categorized as one of internal factors while climate change causing extreme rainfall is external factor. These problems are farming risk that should be faced because it has strong relation with price fluctuation of horticulture products.

One time, product price are very high but in the other time, its price declines sharply. Horticulture price fluctuates and depends on demand quantity while supply quantity is different from food crops for example paddy and maize (FAO, 2016). The main cause of fluctuations in horticultural products is because the number of products is quickly sold out and the short-term demand changes due to certain celebrations.

Potato, cabbage, and scallion have high fluctuation price due to climate change, planting period selection, and postharvest handling is still not optimal yet (Gareta, 2015). In order to overcome this fluctuation price, farmers need to know some strategic alternatives that should be taken for instance by choosing commodities which will give them optimal profit. Unfortunately, the process of decision making depends on environmental uncertainty and full of risks. In consequences, farmers need to rationally decide the best strategy to maximize their objective function which is profit function and utility or to minimize their production as their objective function (Setyowati, 2014).

CITATION: Setyowati, P., B., Toiba, H., Sujarwo, Syafrial, Nugroho, C., P., (2021). Game Theory Application in Decision Making of Horticulture Farming, Agricultural Socio-Economics Journal, 21(1), 59-64 DOI: http://dx.doi.org/10.21776/ub.agrise.2021.021.1.8 
The farming risks encourage farmers to have alternative strategies in anticipating high fluctuations in commodity prices. Therefore, the main problem that must be solved in this study is choosing an alternative strategy as a decision taken by farmers to achieve optimal profits. Alternative strategies can be in the form of horticultural crops that are most suitable for planting in terms of two seasons, namely the rainy and dry seasons.

According to the explanation above, decision making of horticulture farming using game theory approach to determine which commodities that will be cultivated by farmers are needed to be analyzed.

\section{RESEARCH METHODS}

This research was purposively conducted in Wonokitri Village, Tosari Sub District, Pasuruan Regency considering that there are ore than two commodities that are cultivated in one village and each farmer has at least two planting periods in a year. There are 30 respondents for horticulture farmers for potato, cabbage, and scallion.

Decision making under risk and uncertainty is caused by unknown quantity and emergence probability of that condition. Payoff is known but probability of each payoff is still unknown. Farming decision making may relate to commodities type determination, input combination, farming capital use, and any other decisions. The decision that will be taken is optimal or not will bring profits or losses for farmers. In this research case, dry and rainy season are two conditions which are considered in making a decision in terms of maximising profit or minimizing production cost.

Pazek \& Rozman (2009) explains that under uncertainty condition, there are some three requirements which are needed to be fulfilled:

a. There are some strategic alternatives that may be done.

b. Probability of each condition is unknown.
c.There is payoff value as an outcome from strategic alternatives combination.

If farmers will apply monocropping farming system then it is categorized as pure strategy. While applying intercropping farming system is one of combination strategy.

In order to analyze farmers' decision making, rationality assumption using game theory was used. Strategic alternatives A1, A2, A3, ... An will be presented in payoff matrix form consisting of three horticulture commodities that will be planted during rainy and dry season. This matrix will be presented in table 1.

Table 1. Payoff Matrix of Decision Making

\begin{tabular}{ccccc}
\hline & \multicolumn{3}{c}{$\mathrm{S}$} \\
\cline { 2 - 5 } $\mathrm{A}$ & $\mathrm{S}_{1}$ & $\mathrm{~S}_{2}$ & $\ldots$ & $\mathrm{S}_{\mathrm{n}}$ \\
\cline { 2 - 5 } & $\mathrm{p}_{1}$ & $\mathrm{p}_{2}$ & $\ldots$ & $\mathrm{p}_{\mathrm{n}}$ \\
\hline $\mathrm{A}_{1}$ & $\mathrm{R}_{11}$ & $\mathrm{R}_{12}$ & $\ldots$ & $\mathrm{R}_{1 \mathrm{n}}$ \\
$\mathrm{A}_{2}$ & $\mathrm{R}_{21}$ & $\mathrm{R}_{22}$ & $\ldots$ & $\mathrm{R}_{2 \mathrm{n}}$ \\
& & & & \\
$\vdots$ & $\vdots$ & $\vdots$ & $\vdots$ & $\vdots$ \\
$\mathrm{A}_{\mathrm{m}}$ & $\mathrm{R}_{\mathrm{m} 1}$ & $\mathrm{R}_{\mathrm{m} 2}$ & $\ldots$ & $\mathrm{R}_{\mathrm{mn}}$ \\
\hline
\end{tabular}

A $=$ Set of strategic alternative $A_{i}$ (for $i=1,2, \ldots, m$ )

$\mathrm{S}=$ Set of faced condition by $S_{j}$

(for $i=1,2, \ldots, n$ )

$\mathrm{R}=$ Set of payoff $R_{i j}$ by choosing strategic alternative $A_{i}$ if facing $S_{j}$ situation.

$\mathrm{P}=$ Probability distribution of $S_{j}$

In this research, choices of strategic alternatives are choices in determining which horticulture commodities that will be grown: potato, cabbage, or scallion. Set of faced conditions are when farmers got highest and lowest price in which each probability is 0,5 . Gross profit by calculating the difference between framers' income and production cost (fertilizer application) is becoming payoff.

Dillon \& Heady (1960) and Adeoye, et al (2012) state that deciding best strategic alternative towards farmng risks using game theory has some criteria as following: 
Table 2. Criteria of Strategic Alternative Choices

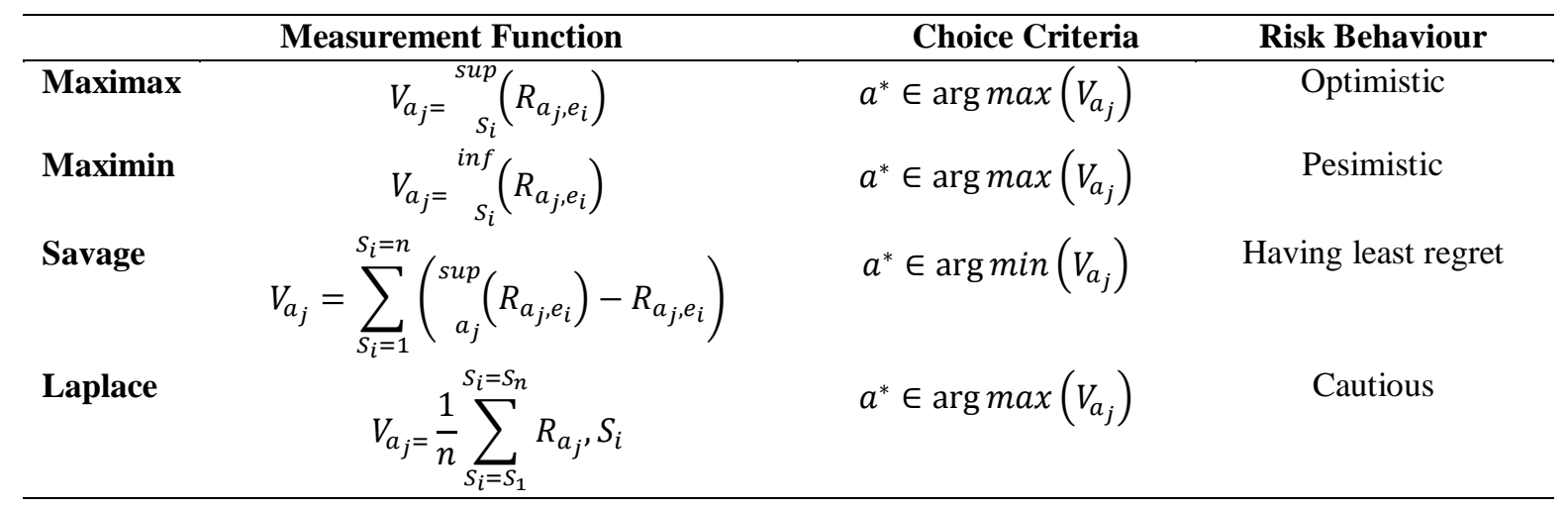

First, measurement function has to be formulated and then according to the choice criteria, risk behaviour of horticulture farmers in dealing with farming risk will be determined. Maximax criteria explains that farmers are risk reverse. It means they are ready to take any farming risks. Maximin criteria describes that farmers are risk averse and in case something bad happens or they get lowest price, they are not at all ready to bear this risk.

Maximax criteria is an approach for the optimist person. The decision maker will consider the maximum payoff from the available alternative options and then select the alternative that will give the best result. The results of these criteria will be in accordance with decision makers who like the highest payoffs and do not hesitate to take risks (Pazek, 2009)

Wald's criteria is also called the maximin which is to choose the smallest payoff value from each alternative strategy, then the largest payoff value will be selected. In other words, the decision maker will compare the smallest payoff results from several strategies then choose the highest value or choose the largest minimum alternative.

The decisions taken are considered pessimistic and very conservative regarding the results that will be obtained in the future. These criteria will appeal to decision makers who are looking for assurance that in the face of the worst conditions there is still a payoff even if the value is small. This is because the smallest payoff value has a greater chance of occurring. So it can be concluded that Wald's criterion is to choose a strategy that will provide income with the least opportunity for decision makers.

Savage criteria aims to avoid regrets, opportunity costs, or losses that arise when certain events happen and the payoff of the chosen alternative is smaller than the possible payoff in that particular situation. After choosing the decision that minimizes the value of the greatest regret. This definition of regret is a lost opportunity at the chosen alternative ( $\mathrm{Ai}$ ) and a certain situation occurs $(\mathrm{Sj})$.
This regret value is obtained from the difference between the max payoff and the payoff for certain alternatives. Similar to Wald's criterion, Savage's criterion is conservative by assuming that the worst condition is the one with the greatest regret (Pazek, 2009).

Laplace stated that no information was available regarding the probability of the payoff received so that the probability was assumed to be the same. So if there are $n$ payoffs, the probability for each payoff is $1 / \mathrm{n}$. This approach also says that the decision maker calculates the expected payoff for each alternative strategy and selects the alternative strategy with the greatest value.

\section{RESULTS AND DISCUSSION}

The agricultural sector is a sector that has played a significant role in the development of the Indonesian economy, such as providing jobs for farming labor, a source of income for the community, providing food and bringing in foreign exchange for the country. One of the agricultural sub-sectors that has produced agricultural products that have high commercial value is the horticulture sub-sector. Apart from providing high income to farmers, vegetables are horticultural commodities that have been able to contribute to national development. Production risk can be caused by two factors, namely controlled factors and uncontrollable factors. Controllable factors, namely the use of inputs or production factors.

The main factor that most influences the high risk of doing business is climate change or it can be categorized as uncontrollable. From these risk factors, farmers carry out treatments or countermeasures to reduce these risks, the most common way of handling is by spraying fungicides, to keep plants from being attacked by fungicides which can result in crop damage. This handling is usually done by farmers when it rains continuously or it can be said that the rain intensity is too high or frequent. 
Planting a number of agricultural commodities at this time is decided based on developments in prices and the growing season for certain commodities. The determination of the types of agricultural commodities to be planted is influenced by various factors whose processes are very complex and dynamic. Therefore, farmers need sufficient knowledge to be able to decide for themselves what types of plants to plant in their gardens. Both agriculture in a broad level and agriculture with a narrow land must both be determined ideally so that the results obtained are more optimal.

According to the research results, the consideration of the respondent farmers in deciding the type of commodity to be planted was the suitability of the land with the type of commodity being planted. They know the suitability of this land from the experience of farming by comparing the commodities planted at harvest. The most preferred commodity other than the main commodity grown by farmers in the research area was potato. Almost all respondent farmers chose potato for the second crop besides the main crop, this refers to the reason for land suitability for the potato crop. The habit that has long been practiced by respondent farmers in the research area is to change the type of crop commodity every harvest season, they do this for various reasons but the most common reason for this behavior is crop rotation or a change in the type of crop commodity. The farmers said that this crop rotation was carried out to maintain soil fertility and prevent crop damage from pests and diseases when they planted the same commodity in every growing season.

Horticulture farmers in the research area have three options to run their farms. Those are potato, cabbage, and scallion. The most important thing that is considered by them in deciding which commodities for their farming system related to land and climate adjustment, ease of crop cultivation, commodities price that farmers get in harvesting period, capital availability, productivity level, and required production cost. In general, they start to plant in the beginning of rainy season where water availability is in high level.

Farming risks always correspond to the decision making process in choosing the best commodities. According to strategic alternative options and obtained payoff in dealing with two different situations which are highest and lowest price is presented by following matrix:
Table 3. Payoff Matrix of Horticulture farmers

\begin{tabular}{ccc}
\hline & \multicolumn{2}{c}{ Payoff } \\
\cline { 2 - 3 } & $\begin{array}{c}\text { Highest } \\
\text { Gross Profit }\end{array}$ & $\begin{array}{c}\text { Lowest } \\
\text { Gross Profit }\end{array}$ \\
\hline Potato Farmer ${ }_{1}$ & $\pi_{1 \mathrm{~T}}$ & $\pi_{1 \mathrm{R}}$ \\
$\vdots$ & $\vdots$ & $\vdots$ \\
Potato $_{\text {Farmer }}$ & $\pi_{10 \mathrm{~T}}$ & $\pi_{10 \mathrm{R}}$ \\
Cabbage $_{\text {Farmer }}$ & $\pi_{11 \mathrm{~T}}$ & $\pi_{11 \mathrm{R}}$ \\
$\vdots$ & & \\
Cabbage $_{\text {Farmer }}$ & $\vdots$ & $\vdots$ \\
Scallion & $\pi_{20 \mathrm{~T}}$ & $\pi_{20 \mathrm{R}}$ \\
Farmer $_{1}$ & $\pi_{21 \mathrm{~T}}$ & $\pi_{21 \mathrm{R}}$ \\
$\vdots$ & & $\vdots$ \\
Scallion & $\vdots$ & $\pi_{30 \mathrm{R}}$ \\
Farmer $_{10}$ & $\pi_{30 \mathrm{~T}}$ & \\
\hline
\end{tabular}

Farmers' behaviour related to face farming risk will be able to determine whether they are optimistic, pessimistic, cautious, or having biggest regret in bearing crop failure. Table 4 serves farmers' behaviour:

Table 41. Farmers' Behaviour in Making a Choice

\begin{tabular}{ccc}
\hline Farmers' & Risk Criteria & Commodity \\
Behaviour & & \\
\hline Optimistic & Maximax & Potato \\
Pessimistic & Maximin & Scallion \\
Cautious & Laplace & Potato \\
$\begin{array}{c}\text { Having least } \\
\text { regret }\end{array}$ & Savage & Cabbage \\
\hline
\end{tabular}

According to the Maximax and Laplace criteria, potato farmers are optimistic, risk reverse, and cautious. It is because they have the highest income per hectare compared to two other farmers. On the other hand, potato cultivation technique is harder than that of cabbage and scallion. That is why they tend to have extra effort in controlling any pest or disease attacks. Most of them decide to grow potato because it has been their tradition and its productivity is high.

Furthermore, compared to cabbage and scallion, planting potato is more profitable and they often get higher price around Rp 12.000,00/kg and lowest price is $\mathrm{Rp} 2.000,00 / \mathrm{kg}$ during rainy season. Pest and disease attacks for this commodity are very high so that they need to regularly spray pesticides and during rainy season, they do it every day. In order to get maximal output, fertilizer should be applied since 1 month after planting period for every 4 days until 20 days before harvesting period.

Scallion farmers are categorized as pessimistic and risk averse. For those who choose 
this commodity, they consider that they do not need much capital, plant treatment is not difficult and in case there is pest and disease attack, pesticide price is affordable. The lowest price they have ever obtained is $\mathrm{Rp} 1.500,00 / \mathrm{kg}$ and the highest price is Rp 10.000,00/kg.

Cabbage farmers have the least regret. The minimum price is $\mathrm{Rp} 300,00 / \mathrm{kg}$ while the maximum price is $\mathrm{Rp} 6.000,00 / \mathrm{kg}$. Cabbage is favourable because its treatment is easy, faster harvesting period, and production cost is less than potato and scallion.

\section{REFERENCES}

Adeoye, IB. Yusuf, SA. Balogun OS. Alabuja F. (2012). Application of Game Theory to Horticultural Crops In South-West Nigeria. ARPN Journal of Agricultural and Biological Science,7(5),372-375.

www.arpnjournals.com/jabs/research_paper s/rp_2012/jabs_0512_405.pdf

Dillon JL, Heady EO. (1960). Theories of Choice In Relation to Farmer Decisions. Research Bulletin 485. Agricultural and Home Economics Experiment Station Iowa State University of Science and Technology. USA
FAO. (2016). The Impact of Supply and Demand. http://www.fao.org/docrep/008/a0185e/a018 5e04.htm.

Gareta, SP. (2015). Ini Penyebab Harga Tomat Bergejolak.

http://www.antaranews.com/berita/512889/i ni-penyebab-harga-tomat-bergejolak.

Pazek K, Rozman C. (2009). Decision Making Under Conditions of Uncertainty in Agriculture: A Case Study of Oil Crops. https://hrcak.srce.hr/file/61873.

Setyowati, PB. (2014). Economic Applications of Non Cooperative Game Theory: Fiscal Competition and Agricultural Economic. Tesis. Université de Caen Basse-Normandie. Perancis 
Putri Budi Setyowati, Hery Toiba, Sujarwo, Syafrial, Condro Puspo Nugroho

This page is intentionally left blank 